\title{
Implications of Ocean Acidification for Marine Microorganisms from the Free-Living to the Host-Associated
}

\section{OPEN ACCESS}

Edited by:

Hongyue Dang,

Xiamen University, China

Reviewed by:

Torsten Thomas,

The University of New South Wales,

Australia

Christine Ferrier-Pagès,

Centre Scientifique de Monaco,

Monaco

${ }^{*}$ Correspondence:

David G. Bourne

david.bourne@jcu.edu.au

${ }^{\dagger}$ Present Address:

Kathleen M. Morrow,

Deparment of Molecular, Cellular and Biomedical Sciences, University of New Hampshire, Durham, NH, USA

Specialty section:

This article was submitted to

Aquatic Microbiology,

a section of the journal

Frontiers in Marine Science

Received: 19 February 2016 Accepted: 29 March 2016

Published: 14 April 2016

Citation:

O'Brien PA, Morrow KM, Willis BL and Bourne DG (2016) Implications of

Ocean Acidification for Marine Microorganisms from the Free-Living

to the Host-Associated.

Front. Mar. Sci. 3:47.

doi: 10.3389/fmars.2016.00047

\author{
Paul A. O’Brien ${ }^{1,2,3}$, Kathleen M. Morrow ${ }^{2 \dagger}$, Bette L. Willis ${ }^{1,3,4}$ and David G. Bourne ${ }^{1,2,3 *}$ \\ ${ }^{1}$ College of Marine and Environmental Sciences, James Cook University, Townsville, QLD, Australia, ${ }^{2}$ Centre for Marine \\ Microbiology and Genetics, Australian Institute of Marine Science, Townsville, QLD, Australia, ${ }^{3}$ AIMS@JCU, College of \\ Marine and Environmental Sciences, James Cook University, Townsville, QLD, Australia, ${ }^{4}$ ARC Centre of Excellence for Coral \\ Reef Studies, James Cook University, Townsville, QLD, Australia
}

Anthropogenic $\mathrm{CO}_{2}$ emissions are causing oceans to become more acidic, with consequences for all marine life including microorganisms. Studies reveal that from the microbes that occupy the open ocean to those intimately associated with their invertebrate hosts changing ocean chemistry will alter the critical functions of these important organisms. Our current understanding indicates that bacterial communities associated with their host will shift as $\mathrm{pH}$ drops by another 0.2-0.4 units over the next 100 years. It is unclear what impacts this will have for host health, however, increased vulnerability to disease seems likely for those associated with reef corals. Natural $\mathrm{CO}_{2}$ seeps have provided a unique setting for the study of microbial communities under OA in situ, where shifts in the bacterial communities associated with corals at the seep are correlated with a decline in abundance of the associated coral species. Changes to global biogeochemical cycles also appear likely as photosynthesis and nitrogen fixation by pelagic microbes becomes enhanced under low pH conditions. However, recent long-term studies have shown that pelagic microbes are also capable of evolutionary adaptation, with some physiological responses to a decline in $\mathrm{pH}$ restored after hundreds of generations at high $\mathrm{pCO}_{2}$ levels. The impacts of ocean acidification (OA) also will not work in isolation, thus synergistic interactions with other potential stressors, such as rising seawater temperatures, will likely exacerbate the microbial response to OA. This review discusses our existing understanding of the impacts of $\mathrm{OA}$ on both pelagic and host-associated marine microbial communities, whilst highlighting the importance of controlled laboratory studies and in situ experiments, to fill the current gaps in our knowledge.

Keywords: ocean acidification, microorganisms, invertebrates, coral, biogeochemical cycle, holobiont, $\mathrm{CO}_{2}$ Seeps, adaptation

\section{INTRODUCTION}

Since the industrial revolution, the oceans have absorbed $\sim 30 \%$ of human generated $\mathrm{CO}_{2}$ emissions, leading to a reduction of seawater $\mathrm{pH}$ by 0.1 units (i.e., more acidic) and equating to a $26 \%$ increase in the concentration of hydrogen ions (Royal Society, 2005; Doney, 2010; Rhein et al., 2013). To put this into perspective, the current average pH of surface seawater is now $\sim 8.1$ (Doney, 2010; Rhein et al., 2013) and seawater pH has 
not dropped below this level in the last 23 million years (Pearson and Palmer, 2000). Furthermore, current emissions modeling data predict an alarming decline in surface ocean pH by a further $0.2-0.4$ units by 2100 (Rhein et al., 2013). Such a shift in the chemistry of the oceans will have profound effects on the organisms that inhabit our marine ecosystems, from the microorganisms through to the largest of the marine mammals (Guinotte and Fabry, 2008). Given ocean pH varies with season, depth, and productivity, some marine organisms may already be experiencing $\mathrm{pH}$ values below levels predicted for the next century (Joint et al., 2011). However, it is the long-term, persistent decline in global ocean $\mathrm{pH}$, termed ocean acidification (OA), which is of particular concern and has gained considerable attention over the last decade (Figure 1). Calcifying organisms are a focal point of research efforts because as the partial pressure of carbon dioxide $\left(p \mathrm{CO}_{2}\right)$ rises, the subsequent concentration of carbonate ions and the saturation state of calcium carbonate $\left(\mathrm{CaCO}_{3}\right)$ minerals declines, making it more difficult for marine organisms to build shells and skeletons (Orr et al., 2005; Doney, 2010; Erez et al., 2011). Comparative studies on the effects of OA on marine microorganisms have lagged far behind in comparison to the speed at which these changes are occurring (Figure 1).

This review explores how a further reduction in ocean $\mathrm{pH}$ may influence processes governed by marine microbes, within both host-associated and pelagic environments. Tropical reef invertebrates are a specific focus, given that coral holobionts have emerged as model habitats for studying microbial influences on host health. Additionally, we highlight volcanically driven $\mathrm{CO}_{2}$ seeps as ideal experimental settings to assess the long-term effects of high $\mathrm{pCO}_{2}$ and reduced $\mathrm{pH}$ on microbial processes. Seep habitats are compared and contrasted with studies conducted under more controlled manipulative conditions that may include additional forces such as temperature within mesocosm experiments. Lastly, we examine the potential for OA to act in synergy with other environmental stressors, causing small and large-scale changes in marine microbial processes.

\section{MARINE MICROBES INFLUENCE GLOBAL PROCESSES AND HOST FITNESS THROUGH SMALL-SCALE INTERACTIONS}

The microorganisms inhabiting our oceans are central to key global processes, such as carbon, nitrogen and sulfur cycling, as well as the exchange of trace gases that have direct impacts on local climate (Moran et al., 2003; Webster and Hill, 2007; Raina et al., 2009, 2010, 2013; Doney, 2010). Bacteria dominate the oceans in terms of abundance, diversity, and metabolic activity (Azam et al., 1983; Giovannoni and Stingl, 2005), and it is in the oceans that approximately half of the global primary production occurs (Field et al., 1998). Heterotrophic and autotrophic bacteria both utilize and contribute substantially to marine primary production, and thus are not only heavily involved in the cycle of carbon, but form the basis of marine ecosystem function (Azam et al., 1983; Pomeroy et al., 2007). Single cell cyanobacteria, for example, have a major impact on the global carbon cycle, with Synechococcus and Prochlorococcus contributing up to 50\% of the fixed carbon in marine systems (Partensky et al., 1999), while heterotrophic bacteria rapidly respire about $50 \%$ of the fixed carbon in marine systems (Giovannoni and Stingl, 2005). Cyanobacteria are also heavily involved in the global nitrogen cycle, with both Trichodesmium and unicellular diazotrophs making significant contributions to $\mathrm{N}_{2}$ fixation in marine systems (Capone et al., 1997; Montoya et al., 2004; Welsh et al., 2008). This important role allows inert $\mathrm{N}_{2}$ to become readily available for use in biological systems thereby supporting marine productivity, and is especially significant in oligotrophic waters such as coral reefs, allowing them to be among the most productive ecosystems in the ocean (Larkum et al., 1988).

Coral reefs occupy less than $1 \%$ of the Earth's marine environment, however they are of immense value as they support $\sim 25 \%$ of the marine biodiversity and millions of people around the globe depend on them for their livelihood (Moberg and Folke, 1999). Recent declines in the health of coral reefs are predicted to cause great social, environmental, and economic consequences (White et al., 2000; Jones G. P. et al., 2004; Hoegh-Guldberg et al., 2007), making them a necessary habitat in which to study the effects of OA. Scleractinian corals build the foundations of these reefs and rely on favorable carbonate ion and aragonite (a mineral form of calcium carbonate) concentrations to lay down their skeletons. Since elevated $\mathrm{CO}_{2}$ reduces both the aragonite and carbonate ion concentrations in seawater, coral reefs are predicted to be the biggest losers in an acidified ocean, greatly reducing the growth of all organisms with calcium carbonate skeletons (Doney et al., 2009; Fabricius et al., 2011). On coral reefs, microorganisms provide essential roles in nutrient cycling, which contributes to ecosystem productivity in nutrient poor waters (see Bourne and Webster, 2013). Microbial communities in reef sediments are responsible for the metabolism of organic matter that is used by the surrounding reef ecosystem (Bourne and Webster, 2013), and benthic nitrogen-fixing bacteria are responsible for an important source of internal nitrogen on coral reefs (Shashar et al., 1994; Cardini et al., 2014).

In addition to the roles microorganisms perform in ecosystem-wide geochemical and nutrient cycling, a wide range of reef invertebrates, including cnidarians, sponges, molluscs, and echinoderms also rely on complex associations with microbes to maintain their health (Lesser and Blakemore, 1990; Rosenberg et al., 2007; Roeselers and Newton, 2012; Webster and Taylor, 2012). Perhaps one of the best studied of these relationships involves the association between scleractinian corals and their microbes, a metacommunity known as the holobiont (Rohwer et al., 2002). The holobiont includes the coral animal, endosymbiotic photosynthetic dinoflagellates (Symbiodinium), and diverse members of the Bacteria, Archaea, and Protista, as well as fungi and viruses (Rohwer et al., 2002; Rosenberg et al., 2007). It has been established for some time that Symbiodinium provide an energy source for their hosts through photosynthesis, but more recently Symbiodinium have also been shown to influence and potentially regulate the intracellular $\mathrm{pH}$ of corals (Venn et al., 2009).Bacteria associated with corals have been shown to be diverse, though the functional roles are poorly understood and only recently have some roles been elucidated (Figure 2). 


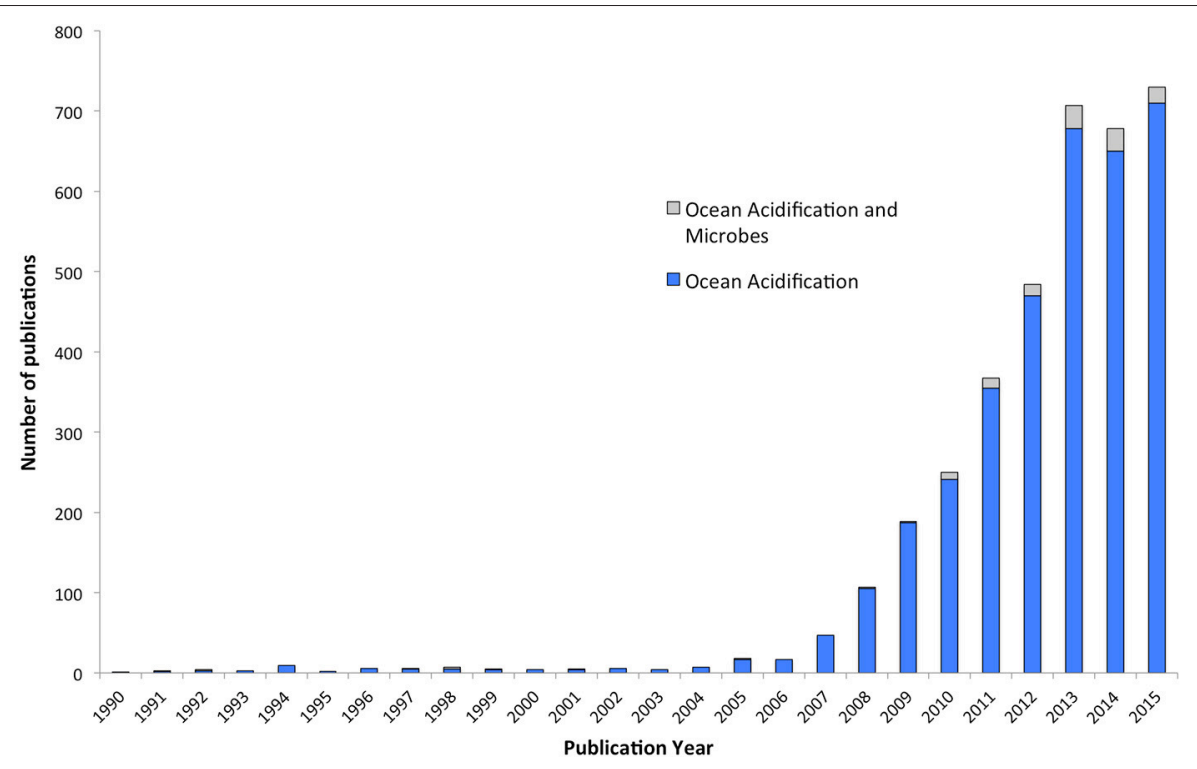

FIGURE 1 | Number of publications based on the key words [ocean acidification] and [ocean acidification and microbes] or [ocean acidification and microorganisms] or [ocean acidification and bacteria], as searched through the Web of Science database. Research on OA has increased dramatically in the past decade, however, little research has been directed toward the implications of OA for microbes.

Examples of the roles coral-associated bacteria perform include nitrogen-fixation (Lesser et al., 2004; Lema et al., 2012, 2014b), which allows their host to exploit inorganic nitrogen, enabling them to thrive in tropical waters where nitrogen is the most limiting nutrient to primary productivity (D'Elia and Wiebe, 1990). Efficient internal recycling of nitrogen with the Symbiodinium is believed to help sustain a healthy symbiosis (Cardini et al., 2015; Rädecker et al., 2015), while carbonfixing cyanobacteria have been said to provide an additional energy source when Symbiodinium densities are low (Fine and Loya, 2002). High levels of dimethylsulfoniopropionate (DMSP), produced by both the coral host and Symbiodinium, are passaged to the surrounding water and likely provide an ideal nutrient source for coral-associated bacteria (Raina et al., 2009, 2010, 2013). Bacterial metabolism of DMSP is then proposed to provide antioxidants that protect the coral tissues against harmful reactive oxygen species (Sunda et al., 2002; Yost et al., 2010). Coral-associated bacteria not only produce nutrients utilized by the coral and Symbiodinium, but also protect the coral from pathogens through the production of potent antibiotics and by maintaining a niche otherwise available to opportunistic microbes (Ritchie, 2006). Functions of associated prokaryotes are not limited to corals with many other coral reef invertebrates benefitting from these microbial relationships (Duperron et al., 2009; Schmitt et al., 2012; Webster and Taylor, 2012). However, the majority of studies examining host-associated microbial communities on coral reefs remain largely descriptive. There is a need for further research into the functional roles of hostassociated bacteria, the effects of OA on microbial metabolic processes, and how subsequent community shifts might affect overall host fitness.

\section{IMPLICATIONS OF OA FOR HOST-ASSOCIATED MARINE MICROORGANISMS}

Marine invertebrates, like all marine organisms, have evolved in environments rich in microorganisms, and have formed specific mutualistic relationships that persist through generations (McFall-Ngai, 1999). Sponges harbor dense microbial communities and in some cases this may comprise up to $40 \%$ of the sponges' total biomass (Webster and Hill, 2007; Webster and Taylor, 2012). However, despite the ecological importance of sponges on reefs, very little research has focused on how the associated microbial communities of sponges will be influenced by low pH (Bell et al., 2013). A limited number of studies suggest that sponge populations will undergo profound changes under low $\mathrm{pH}$ conditions (Goodwin et al., 2014; Morrow et al., 2014), and are one group of marine invertebrates that may benefit from projected climate change and OA scenarios. Thus, it has been argued that coral reefs may become sponge-dominated reefs under future ocean conditions (Bell et al., 2013). Shifts in the associated microbial communities are thought to be one of the mechanisms driving these changes at the sponge community level (see later section $\mathrm{CO}_{2}$ seeps: a window into the future). Such changes in microbial communities have been found following other environmental stressors, such as elevated temperature and heavy metals, where shifts in the normally stable microbial communities have been linked with a decline in sponge health (Webster et al., 2001, 2008; Fan et al., 2013). However to date, no studies have examined the effects of $\mathrm{pH}$ on spongeassociated microbial communities under controlled laboratory conditions. 


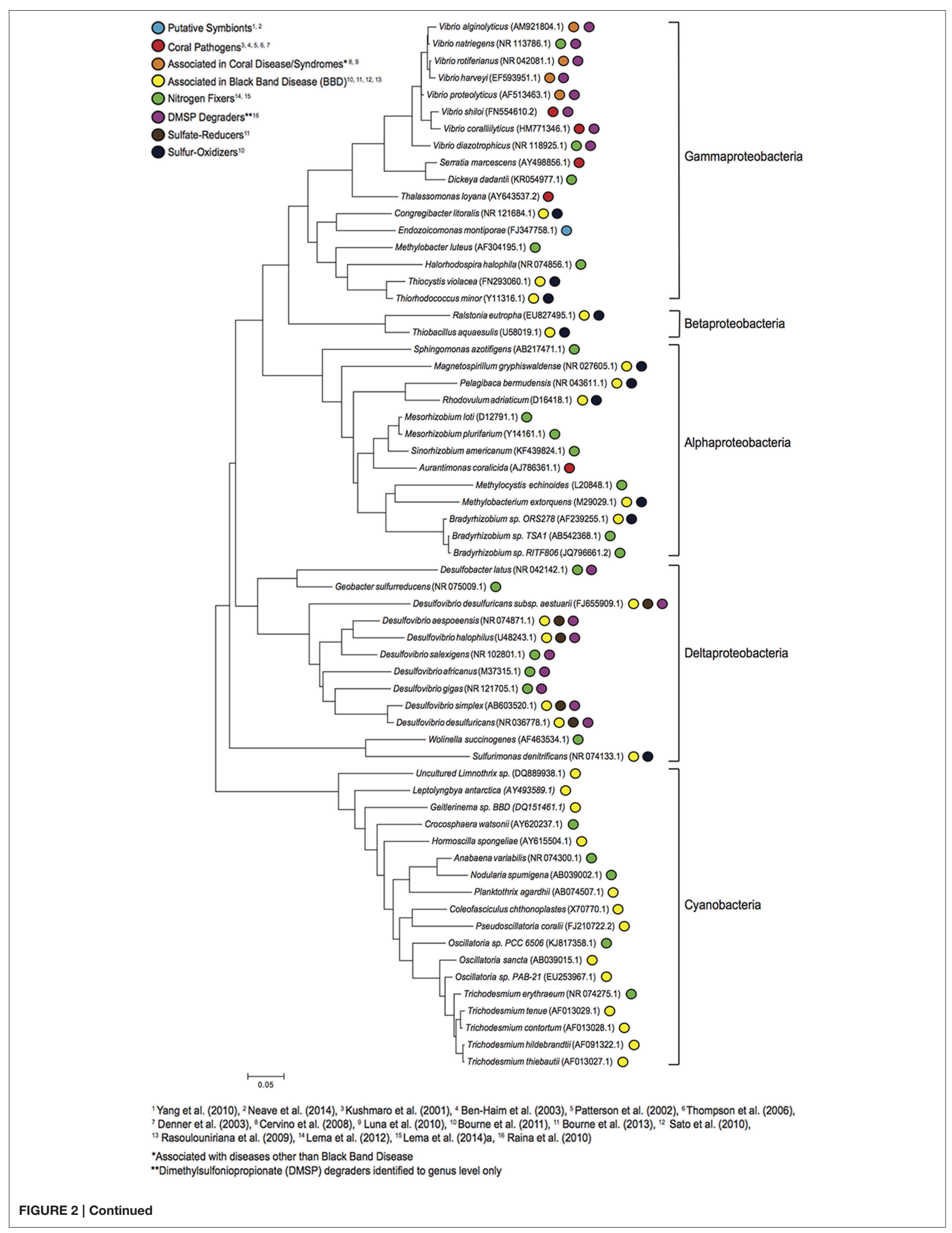




\section{FIGURE 2 | Continued}

Phylogenetic relationships among coral-associated bacteria with described functions. Evolutionary history was inferred by using the Maximum Likelihood method based on the Kimura 2-parameter model (Kimura, 1980). The high number of bacteria that are shown with disease associations (coral pathogens, associated with BBD consortium, associated with coral diseases/syndromes) illustrates that much of the research describing coral-associated bacteria has been focussed on disease. Evolutionary analysis was conducted using MEGA6 (Tamura et al., 2013).

Other filter feeding invertebrates, such as bivalves, also host symbiotic bacteria, and of particular interest are those that host chemosynthetic bacteria. Identified in five bivalve families thus far, chemosynthetic bacteria have the ability to convert $\mathrm{CO}_{2}$ or methane $\left(\mathrm{CH}_{4}\right)$ into organic compounds, providing the host with nutrients and allowing it to survive in a variety of habitats, including those as acidic and harsh as hydrothermal vents (Roeselers and Newton, 2012). Under future OA conditions, it may be symbioses such as these that will become advantageous in a high $\mathrm{CO}_{2}$ world. However, not all microorganisms associated with invertebrates are beneficial, and through filter feeding, bivalves may accumulate large numbers of pathogenic bacteria (Asplund et al., 2014). While such accumulations of pathogens can usually occur without the host becoming affected, the blue mussel pathogen Vibrio tubiashii was shown to be more infectious under low pH conditions (Asplund et al., 2014). With the enormous range of invertebrate-microbial associations that may be influenced by $\mathrm{OA}$, there is an urgent need to address the paucity of knowledge in this field of research.

Changes in host-microbial associations (e.g., community shifts) are often considered detrimental to the host, although they may provide a means for rapidly adapting to environmental change, as suggested by the coral probiotic hypothesis and hologenome concept (Reshef et al., 2006; Zilber-Rosenberg and Rosenberg, 2008). The hologenome concept considers the collective genomic content of the host and microbial constituents as a single unit of evolutionary selection. This concept has gained recent popularity (Bordenstein and Theis, 2015), but is contested by others, who suggest we consider that microorganisms can maintain intimate associations with their host over significant time-frames without undergoing natural selection to primarily benefit the host (Moran and Sloan, 2015). Evidence that microbial communities overlap among host species and may differ with geographic location (Littman et al., 2010), and season (Li et al., 2014), suggests that microbial communities do shift to some extent to suit the surrounding environment, which supports the probiotic hypothesis. However, if the host and its associated microbes function as a single unit of selection (i.e., a hologenome), one would expect a spatially and temporally stable microbiome that is ubiquitously associated with its host species. Considering this, current evidence suggests that host species and their associated microorganisms are better represented as holobionts or metaorganisms, rather than as hologenomes. Understanding the coevolution of corals and their associated microbiomes is a current research focus, which will help to further establish the appropriateness of these alternative models (Bordenstein and Theis, 2015; Moran and Sloan, 2015).

On tropical coral reefs, the coral holobiont is emerging as a model system for exploring host-microbial interactions (Bourne and Webster, 2013), and much of the remaining research exploring the impact of OA on host-associated microbes has been focused here. Using aquaria-based experiments, coral-associated bacterial communities have been shown to change in response to decreasing $\mathrm{pH}$, with potential shifts toward a more diseaseassociated state (Vega Thurber et al., 2009; Meron et al., 2011; Webster et al., 2013a). In Acropora eurystoma, changes to bacterial communities were documented in the tissues, skeleton, and mucus of colonies exposed to $\mathrm{pH} 7.3$ for 10 weeks, compared with those exposed to ambient $\mathrm{pH} 8.2$ (Meron et al., 2011). One notable change was an increase in bacteria belonging to Vibrionaceae and Alteromonadaceae, which have both previously been associated with stressed or diseased corals (Bourne et al., 2008; Sunagawa et al., 2009; Figure 2). An increase in antibacterial activity was also seen at low $\mathrm{pH}$ and was attributed mostly to an increase in Vibrio sp., suggesting a mechanism for host invasion (Meron et al., 2011). Disease-associated microbes were also detected when colonies were exposed to $\mathrm{pH}$ levels 1.4 units below ambient (8.1), including bacteria related to the phylum Bacteroidetes and disease-associated fungi (Vega Thurber et al., 2009). Vega Thurber also detected an increase in genes encoding for resistance to antibiotics and toxins, as well as an increase in virulence genes, which may have facilitated the increase in disease-associated microbes at low $\mathrm{pH}$. However, it should be noted that the $\mathrm{pH}$ conditions used in studies by Meron et al. (2011) and Vega Thurber et al. (2009) were below what is expected over the next 100 years and may represent unrealistic OA conditions.

A similar trend was again detected in A. eurystoma, along with foraminifera and crustose coralline algae (CCA), when $\mathrm{pH}$ was reduced from 8.1 to 7.9 (Webster et al., 2013a). After 6 weeks exposure to low $\mathrm{pH}$, microbial profiles were significantly different to those at $\mathrm{pH} 8.1$, and in the case of A. eurystoma, included a loss of sequences that were affiliated with the Proteobacteria and previously shown to be associated with healthy corals (Raina et al., 2009; Sato et al., 2010; Sunagawa et al., 2010). Significant shifts in the microbial biofilm associated with CCA as a result of reduced $\mathrm{pH}$ has also correlated with a reduced ability of CCA to induce coral larval settlement, which is an additional concern for the stability and/or recovery of reefs globally (Webster et al., 2013b). Taken together, the above results suggest an increase in microbial instability with impacts for many coral reef organisms, potentially leading to heightened disease susceptibility due to a shift in their normal microbiome, antibacterial, and virulence activity.

Not only is the microbial community associated with marine invertebrates likely to shift under future OA conditions, but the functional roles these communities perform also appear to be influenced. For the first time, evidence has shown that nitrogen $\left(\mathrm{N}_{2}\right)$ fixation by coral-associated bacteria can be affected by OA (Rädecker et al., 2014). Under high $p \mathrm{CO}_{2}$ conditions (1080 $\mu \mathrm{atm}), \mathrm{N}_{2}$ fixation associated with the Seriatopora hystrix holobiont was significantly reduced by $53 \%$ compared with ambient $p \mathrm{CO}_{2}$ conditions ( $486 \mu \mathrm{atm}$ ). This is in contrast to the planktonic cyanobacterium, Trichodesmium, where $\mathrm{N}_{2}$ fixation 
has shown to become enhanced under high $p \mathrm{CO}_{2} /$ low $\mathrm{pH}$ conditions (Levitan et al., 2007; Liu et al., 2010). Why $\mathrm{N}_{2}$ fixation appears to decline in the coral holobiont under high $\mathrm{pCO}_{2}$ conditions is currently unknown, however it is suggested this may be caused by an energy trade-off within the holobiont due to the increased energy demand by calcification under high $p \mathrm{CO}_{2}$ conditions (Rädecker et al., 2014).

Whilst the above short-term laboratory studies provide important preliminary insight into how microbial communities and their functions may change under future OA conditions, care must be taken when interpreting conclusions due to potential pitfalls related to organism handling, experimental design, and time-scale. A recent review of OA studies showed that in 465 studies published between 1993 and 2014, 95\% of these either used inappropriate experimental design or data analysis, or did not provide enough methodological details to determine the precise design (Cornwall and Hurd, 2016). For instance, some experiments were limited in aquaria or mesocosm replication, leading to pseudoreplication among replicates. Many laboratory studies also occured over short time periods (days to weeks), when realistically the effects of OA on marine organisms will occur over much longer more subtle time scales. Thus there is a push for long-term, highly replicated, mesocosm studies to better simulate the potential implications of OA on coral reef ecosystems (Leblud et al., 2014). In the meantime, additional research endeavors have utilized unique marine environments where the $\mathrm{pH}$ is naturally lower than ambient ocean conditions due to upwelling or $\mathrm{CO}_{2}$ seepage into the sediments and water column. In these areas, organisms are already living unmanipulated under high $p \mathrm{CO}_{2} /$ low $\mathrm{pH}$ conditions that are often representative of predicted levels for the next century.

\section{$\mathrm{CO}_{2}$ SEEPS: A WINDOW INTO THE FUTURE}

Volcanic $\mathrm{CO}_{2}$ seeps provide a natural and unique experimental setting to assess the long-term effects of $\mathrm{OA}$ on marine organisms in situ (Hall-Spencer et al., 2008; Fabricius et al., 2011, 2014; Borell et al., 2014; Morrow et al., 2014). In Papua New Guinea (PNG), for example, the D'Entrecastraux Islands of the Milne Bay province contain reefs where volcanic seeps release $99 \%$ pure $\mathrm{CO}_{2}$ into the surrounding sediments and sea water. At these seeps, $\mathrm{pH}$ is $\sim 7.8$ (however varies with intensity and proximity to the seep) and reflects what is predicted for the next century (Figure 3). Compared with benthic invertebrate communities on nearby reefs that are exposed to the same temperatures, currents and light, seep communities show dramatic changes in community structure, abundance and diversity (Fabricius et al., 2011, 2014; Morrow et al., 2014). The mechanism(s) underlying these community changes at high $p \mathrm{CO}_{2}$ sites is unclear however, recent evidence suggests shifts in host-associated microbial communities at low $\mathrm{pH}$ sites may contribute to host fitness and success (Morrow et al., 2014).

To investigate the effects of elevated $\mathrm{pCO}_{2}$ on hostassociated microbes, Morrow et al. (2014) examined the bacterial communities associated with the corals Acropora millepora and Porites cylindrica at a $\mathrm{CO}_{2}$ seep in PNG. Both corals were less abundant at the $\mathrm{CO}_{2}$ seep, and were found to host

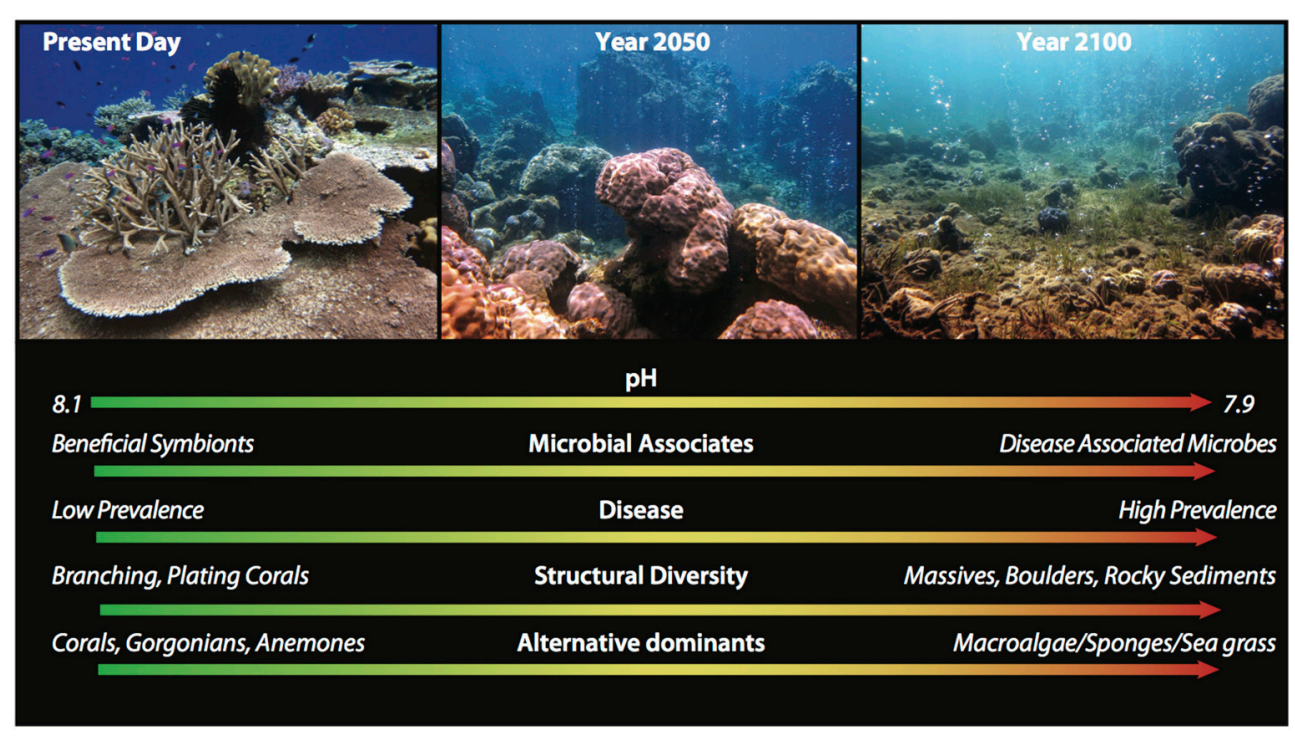

FIGURE 3 | Photos, taken along a pCO2/pH gradient in Papua New Guinea (year 2014), and text depict three potential scenarios for coral reefs under present day and future (year 2050 and 2100) OA conditions if we continue on current predicted $\mathrm{CO}_{2}$ emissions trajectories. Present Day illustrates a healthy coral reef with high structural complexity and diversity that is likely colonized by beneficial microbial associates and experiences a low incidence of disease. As $\mathrm{pCO}_{2}$ increases, scenarios for years 2050 and 2100 illustrate the successional degradation of coral reef heterogeneity (structural diversity), destabilization of microbial associations and increase in disease, transitioning to an alternative stable state composed of competitive dominants (e.g., sponges, macroalgae) and/or sediment/rubble. Arrows from green to red indicate the positive to negative changes a coral reef might experience over time. (Photo credit: K. Morrow). 
distinctly different microbial communities compared with corals at control sites. This was primarily driven by a decrease in Gammaproteobacteria at the seep site, specifically a reduction in the relative abundance of Endozoicomonas spp. in $A$. millepora corals. This putative symbiont has been found in high abundance in other coral species (Morrow et al., 2012; Bayer et al., 2013), and is thought to contribute to the nutritional requirements and defense system of their invertebrate hosts (Yang et al., 2010; Neave et al., 2014; Figure 2). In a similar study, two Mediterranean coral species, Balanophyllia europaea, and Cladocora caespitosa, were transplanted along a $\mathrm{pH}$ gradient at a $\mathrm{CO}_{2}$ vent in the Gulf of Naples, Italy. After 7 months, neither species demonstrated a significant shift in microbial community composition along the $\mathrm{pH}$ gradient of 7.3-8.1 (Meron et al., 2012). However, changes in the relative abundance of bacteria in the class Gammaproteobacteria were apparent in the tissues of both corals increasing in C. caespitosa and decreasing in B. europaea at low $\mathrm{pH}$. An increase in bacteria related to the Bacteroidetes were also found in B. europaea corals, a phylum also found in higher abundance within the lesions of black band disease (Barneah et al., 2007). However, the corals transplanted in this study do not normally occur in the area of the vent, and therefore may not illustrate the microbial community associated with corals adapted to living at lower $\mathrm{pH}$ conditions over extended time periods. Furthermore, no data were provided for bacterial communities associated with corals prior to transplantation from control to seep sites. Nevertheless, it shows potential resilience of some coralmicrobial associations, while others may be more susceptible to reduced $\mathrm{pH}$.

Research at $\mathrm{CO}_{2}$ seeps has also shown that coral physiology can be influenced by elevated $\mathrm{pCO}_{2}$ levels, which may indirectly influence the associated microbial community. For instance, at the PNG $\mathrm{CO}_{2}$ seeps, Acopora millepora was found to have an increase in net photosynthesis rates and a decrease in dark calcification rates at the seep (862 $\mu \mathrm{atm})$ in comparison to the control site (323 $\mu \mathrm{atm}$; Strahl et al., 2015). A healthy coral host produces a complex mixture of metabolites as a result of normal cellular homeostasis that can drive shifts in coralassociated microbial communities (Raina et al., 2010; Nelson et al., 2013). Common marine bacteria such as the Bacteroidetes, Altermonadaceae, and Vibrionaceae are able to colonize such surfaces and take advantage of the enriched organic matter (Dang and Lovell, 2016). However, corals that are sensitive to changes in surrounding $\mathrm{pH}$ will divert resources away from key metabolic processes, thereby changing the amount and composition of the exudates released and subsequently influencing the associated microbial consortia. As discussed previously, the microbial community associated with $A$. millepora was different at the seep site compared to the control (Morrow et al., 2014). It may be that the changed physiology of the host, in addition to the direct effects of elevated $\mathrm{pCO}_{2}$ and lowered $\mathrm{pH}$, influences the associated microbial community. Future research would benefit from correlative studies that examine the impact of host physiology on host-associated microbial communities, particularly when environmental conditions appear to have disparate impacts on host physiology. For example, a small number of coral and sponge species appear to be more tolerant of high $\mathrm{pCO}_{2}$ /low $\mathrm{pH}$ conditions in PNG and provide an ideal system for examining these changes (Fabricius et al., 2011; Strahl et al., 2015).

Seagrasses and sponges have also been shown to host significantly different microbial communities at $\mathrm{CO}_{2}$ seep sites, when compared with control sites of ambient $\mathrm{pH}$. Seagrasses host epiphytic biofilms, which are known to affect seagrass physiology, as well as their interactions with other reef organisms (SandJensen, 1977; Bengen et al., 2011). Evidence from $\mathrm{CO}_{2}$ seeps in PNG suggests that at low $\mathrm{pH}$ these communities show a pronounced shift in both prokaryotic and eukaryotic assemblages when compared with control sites (Hassenruck et al., 2015). Specifically, increases in bacteria associated with coral diseases (Fusobacteria and Thalassomonas) were found at the seep site, raising concerns about the increase in susceptibility of disease on coral reefs in a high $\mathrm{CO}_{2}$ environment, as well as the potential for seagrasses to act as reservoirs for coral pathogens (Sweet et al., 2013). Sponges, like corals, also consist of a very different community at $\mathrm{CO}_{2}$ seep sites compared with nearby reefs of ambient pH (Fabricius et al., 2011; Goodwin et al., 2014; Morrow et al., 2014). At a PNG $\mathrm{CO}_{2}$ seep, both Cinachyra sp. and Coelocarteria singaporensis sponges are significantly more abundant at the seep site, while other species, such as Stylissa massa, are less abundant (Morrow et al., 2014). An analysis of the microbial communities associated with sponges located at both seep and ambient control sites revealed significant shifts in associated microbial communities (Morrow et al., 2014). Most notably, the two more abundant sponge species at the seep site hosted significantly more Cyanobacteria-related bacteria in the genus Synechoccocus, a photosymbiont that is known to contribute up to $50 \%$ of the carbon demand of sponges (Erwin and Thacker, 2008). This illustrates how a drop in $\mathrm{pH}$ can potentially benefit the host through a shift in associated microbes that provide additional nutritional resources. Thus, although many organisms will be detrimentally impacted by future OA conditions, some hosts may be able to take advantage of their microbial partners ability to adapt more readily to shifting environmental conditions, which may lead to fundamental changes in ecosystem structure. Moreover, host physiology will likely cause $\mathrm{pH}$ gradients on the surface or within tissues of the host (Kühl et al., 1995; De Beer and Larkum, 2001), and may be contrasted between $\mathrm{CO}_{2}$ producing organisms (e.g., through respiration) and $\mathrm{CO}_{2}$ consuming organisms (e.g., through photosynthesis), resulting in differential responses of host-microbial communities to reduced $\mathrm{pH}$. Likewise, the effect of host physiology on host $\mathrm{pH}$ may represent a key difference in the response of host-associated microbial communities to OA, compared to free-living microbial communities.

\section{LIKELY RESPONSES OF FREE-LIVING MARINE MICROORGANISMS TO OA}

The response of pelagic marine microorganisms to OA, and subsequent effects on biogeochemical processes, are critical questions with global implications. Pelagic marine microbes are 
naturally exposed to fluctuating $\mathrm{pH}$, and populations in some environments already experience $\mathrm{pH}$ levels lower than what is predicted for the rest of the century, suggesting that some microbes may already possess the means to cope with rapid changes in pH (Joint et al., 2011). However, short-term studies have shown significant changes in calcification rates, growth rates, and primary production in coccolithophores at high $p \mathrm{CO}_{2}$ levels (Riebesell et al., 2000; Iglesias-Rodriguez et al., 2008; Langer et al., 2009). Initial reports stated that calcification was likely to decrease in coccolithophores with increasing $\mathrm{CO}_{2}$ concentrations (Riebesell et al., 2000; Zondervan et al., 2001), however further studies have shown that consequences are not so clear. Following contradictory results of increasing calcification with increasing $\mathrm{CO}_{2}$ in Emiliania huxleyi (Iglesias-Rodriguez et al., 2008), it was highlighted that E. huxleyi shows strain specific responses to increases in ocean $p \mathrm{CO}_{2}$ concentrations, which likely explains much of the variation in results with studies using different cultures (Langer et al., 2009). Furthermore, this demonstrated that short-term culture-based studies are not sufficient to draw conclusions on how microorganisms will respond to OA.

Most marine microbes have short generation times, from hours to days under favorable conditions, in addition to highly versatile metabolic repertoires, which provides significant potential for acclimation and/or adaptation to decreasing $\mathrm{pH}$ over large temporal scales. This potential was realized when Lohbeck et al. (2012) tested for evolutionary adaptation in the globally distributed coccolithophore, E. huxleyi, over $\sim 500$ generations. Cultures were grown under three different $p \mathrm{CO}_{2}$ conditions $(400,1100$, and $2200 \mu \mathrm{atm})$, and it was found that those grown under high $p \mathrm{CO}_{2}$ conditions $(2200 \mu \mathrm{atm})$ showed significantly higher rates of growth and particulate inorganic carbon (PIC) production than those grown under ambient $(400 \mu \mathrm{atm})$ conditions, when exposed to high $p \mathrm{CO}_{2}$ conditions. Further evidence of evolutionary adaptation was seen in the physiological response of the coccolithophore Gephyrocapsa oceanica (Jin et al., 2013). While low-level adaptation was discovered in terms of growth, cells showed a striking adaptation in elemental composition. Cell content and production rates for both particulate organic carbon (POC) and particulate organic nitrogen (PON) shifted back to ambient $p \mathrm{CO}_{2}$ values $(390 \mu \mathrm{atm})$ after $\sim 670$ generations under high $p \mathrm{CO}_{2}$ conditions $(1000 \mu \mathrm{atm})$. Overall, the above results suggest acclimation of growth, calcification and photosynthetic carbon acquisition in coccolithophores to the heightened $p \mathrm{CO}_{2}$ levels.

Marine microorganisms contribute to the carbon cycle via photosynthesis and the production of a calcium carbonate shell $\left(\mathrm{CaCO}_{3}\right)$. Therefore, understanding their ability to adapt to OA will have important implications. For example, if coccolithophores, the main calcifying phytoplankton, increase in calcification with $\mathrm{OA}$, this would likely shift the ocean carbonate system toward a higher seawater $\mathrm{pCO}_{2}$ concentration and promote $\mathrm{CO}_{2}$ outgassing, since the calcification reaction produces $\mathrm{CO}_{2}$. On the other hand, a more likely decline in coccolithophore calcification could lead to a negative feedback on atmospheric $\mathrm{CO}_{2}$ concentrations through reduced $\mathrm{CO}_{2}$ production (Zondervan et al., 2001; Iglesias-Rodriguez et al.,
2008; Hutchins, 2011). There is still no consensus as to how these microorganisms will respond to OA however, a crucial clue may lie in ancient marine sediment cores, which show a decrease in coccolith mass as $\mathrm{CO}_{2}$ increases (Beaufort et al., 2011). Secondly, changes to the photosynthetic capacity in microorganisms due to reduced $\mathrm{pH}$ could also lead to profound changes in the carbon cycle. Cyanobacteria, for instance, contribute up to $50 \%$ of the fixed carbon in marine systems and thus represent a critical component of the global carbon cycle (Partensky et al., 1999). Although physiological responses to changes in $\mathrm{pH}$ are not uniform across cyanobacterial species, many show an increase in photosynthetic ability with increases in $\mathrm{pCO}_{2}$ (Hutchins et al., 2007; Kranz et al., 2009; also see review Liu et al., 2010). Since the photosynthesis reaction uses $\mathrm{CO}_{2}$, this may lead to an additional negative feedback on $\mathrm{CO}_{2}$ concentrations.

The nitrogen cycle is another biogeochemical cycle where marine microbes have a central role (Ward, 2000), and has a high potential to be fundamentally altered by OA. As the $\mathrm{pH}$ of seawater decreases, more ammonia molecules $\left(\mathrm{NH}_{3}\right)$ are converted to ammonium ions $\left(\mathrm{NH}_{4}^{+}\right)$causing a shift in the equilibrium. This means less oxidation of ammonia to nitrite $\left(\mathrm{NO}_{2}^{-}\right)$by ammonia-oxidizing microbes, and therefore less oxidation of nitrite to nitrate $\left(\mathrm{NO}_{3}^{-}\right)$and an overall reduction of marine nitrification (Webster and Hill, 2007). Furthermore, denitrification, another step in the nitrogen cycle controlled by bacteria (Capone, 2000), may also be reduced because of the decline of nitrite and nitrate ions, ultimately causing a buildup of fixed nitrogen, with potential eutrophication implications (Webster and Hill, 2007). Lastly, $\mathrm{N}_{2}$ fixation by cyanobacteria in the genus Trichodesmium have consistently been shown to increase with elevated $p \mathrm{CO}_{2}$ (Levitan et al., 2007; Liu et al., 2010). This group contributes $\sim 50 \%$ of the total marine fixed $\mathrm{N}_{2}$ (Capone et al., 2005), thus greater available nitrogen coupled with decreased denitrification, could further add to the build-up of fixed nitrogen in the ocean (Figure 4).

Experiments using microcosms and mesocosms have also proved useful in understanding the community effects of $\mathrm{OA}$ on pelagic marine microbes. Collectively, these studies have illustrated that elevated $\mathrm{pCO}_{2}$ and declining ocean $\mathrm{pH}$ can disrupt the community equilibrium, leading to further changes in biogeochemical cycles as new species become dominant (Riebesell et al., 2007; Liu et al., 2010; Krause et al., 2012, 2013; Bowen et al., 2013). For instance, Riebesell et al. (2007) used mesocosms to demonstrate multiple shifts in the dominant phytoplankton taxa as a consequence of increased $\mathrm{CO}_{2}$, and showed a net increase in inorganic carbon consumption by the community. Changes in community structure of ammoniaoxidizing bacteria (AOB) have also been shown in response to decreasing $\mathrm{pH}$, owing to the increase in relative abundance of the Nitrosomonas ureae clade (Bowen et al., 2013). This group is able to switch to urea as an energy source, which may underpin its success at low $\mathrm{pH}$ levels where the availability of $\mathrm{NH}_{3}$ is decreased (Pommerening-Roser and Koops, 2005; Figure 4). Whether or not these changes in community structure have the ability to offset potential alterations to the nitrogen cycle is yet to be elucidated. Moreover, these studies have 


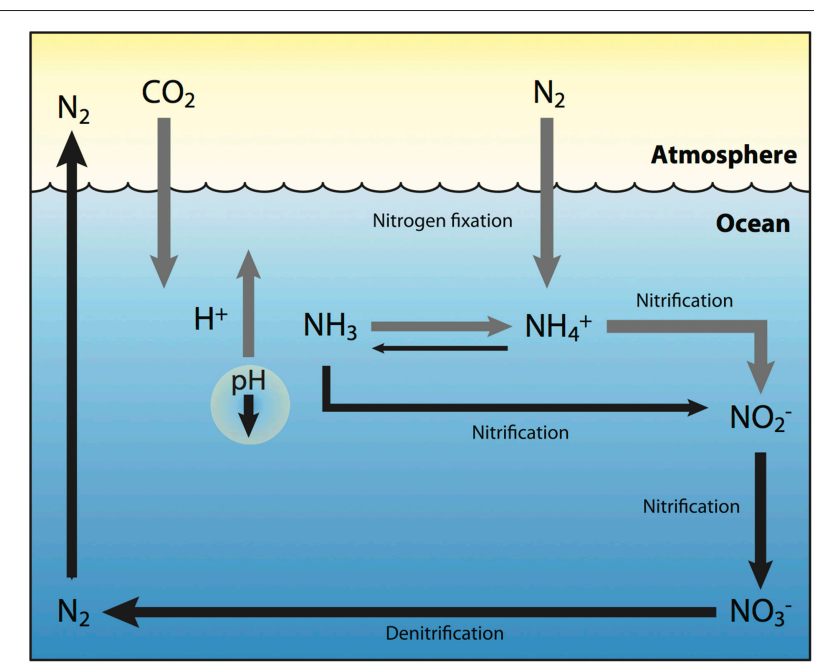

FIGURE 4 | Changes to the marine nitrogen cycle under future ocean acidification conditions. As additional $\mathrm{CO}_{2}$ is absorbed by the ocean and reacts with water molecules $\left(\mathrm{H}_{2} \mathrm{O}\right)$, carbonic acid is formed and broken down into both bicarbonate $\left(\mathrm{H}_{2} \mathrm{CO}_{3}\right)$ and hydrogen $\left(\mathrm{H}^{+}\right)$ions (gray arrow), which reduces bioavailable carbonate and decreases ocean $\mathrm{pH}$ (black arrow). This is likely to enhance nitrogen fixation by diazatrophs (gray arrow), which utilize $\mathrm{H}^{+}$ ions to convert $\mathrm{N}_{2}$ into bioavailable forms such as ammonia $\left(\mathrm{NH}_{3}\right)$ and ammonium ions $\left(\mathrm{NH}_{4}^{+}\right)$. However, as $\mathrm{pH}$ decreases, and more ammonia molecules are converted to ammonium ions (gray arrow), there is less oxidation of ammonia to nitrite $\left(\mathrm{NO}_{2}^{-}\right)$, resulting in an overall decrease in nitrification and denitrification (black arrows). This in turn would lead to a further build up of fixed nitrogen in the ocean, with the potential consequence of eutrophication. Gray arrows represent an increase while black arrows represent a decrease in the associated process.

occurred over days to weeks and therefore assess the shortterm "shock-effects" on these communities, highlighting the need for more long-term studies to fully comprehend the effect of OA on pelagic microbes (Liu et al., 2010; Godbold and Calosi, 2013).

Long-term, in situ microbial time-series studies provide a powerful alternative to mesocosm studies for investigating marine microbial processes and dynamics. Such "microbial observatories" have changed the way we understand microbial involvement in biogeochemical cycles and enabled the discovery of novel microorganisms (such as Prochlorococcus spp.) and metabolic pathways (Steinberg et al., 2001; Karl and Church, 2014). For instance, the Hawaiian Ocean Time-series (HOT) was influential in recognizing the role of marine microbes in the global carbon cycle (Karl and Church, 2014), while the Bermuda Atlantic Time-series has illustrated that biogeochemical variability is ultimately tied to larger-scale climatic changes (Steinberg et al., 2001). Moreover, the Western Channel Observatory (WCO) located in the English Channel has shown seasonal variation in the structure and dynamics of microbial communities and linked this with environmental variables, including temperature and nutrients (Gilbert et al., 2009, 2012). Recently, Sunagawa (2015) utilized 7.2 terabases of metagenome data sequenced from 243 Tara Ocean samples collected across the globe and determined that temperature was the strongest factor in shaping pelagic microbiome composition. While these observations have yet to address the issue of $\mathrm{OA}$ and marine microbes, they have no doubt provided a valuable baseline to which future microbial dynamics and processes can be compared. The establishment of new time-series programs in other waters around the globe will vastly improve our understanding of how marine microorganisms are influenced by OA (as well as other key environmental variables) and contribute to a potentially instrumental global collaboration (Gilbert et al., 2010).

\section{SYNERGISTIC ENVIRONMENTAL STRESSORS: TEMPERATURE, POLLUTION, AND OA}

The close coupling of OA with other anthropogenically-driven environmental stressors, notably ocean warming, means that OA will not occur in isolation (Boyd, 2011). A warming ocean is one of the most widely documented outcomes resulting from the continued global emission of climate gases (including $\mathrm{CO}_{2}$ and methane) (Domingues et al., 2008; Rhein et al., 2013), and like OA will affect marine microbes globally. Although, the joint effects of increased ocean $p \mathrm{CO}_{2}$ and temperature on the growth and physiology of marine microbes is still comparatively unknown, results from $\mathrm{Fu}$ et al. (2007) suggest the effects are synergistic, with increased $p \mathrm{CO}_{2}$ causing greater changes at higher temperatures. Growth rates of Synechococcus were only slightly enhanced under high $p \mathrm{CO}_{2}$ conditions but were doubled when combined with elevated temperature. Furthermore, photosynthetic efficiency and maximum carbon fixation were both greatest when the stressors were combined. This may be explained through the enzymatic dark reactions of photosynthesis, which are sensitive to both $\mathrm{CO}_{2}$ and temperature (Beardall and Raven, 2004; Fu et al., 2007). However these responses were not consistent when studied in Prochlorococcus, further highlighting differences among cyanobacterial species. Likewise, coccolithophores also demonstrate synergistic responses under increased temperature and $p \mathrm{CO}_{2}$. The optimum $\mathrm{CO}_{2}$ levels for growth, organic carbon fixation and calcification have been shown to shift toward higher $p \mathrm{CO}_{2}$ concentrations with increasing temperature (Sett et al., 2014). This combined response may explain the increase in coccolithophore occurrence in the North Atlantic. Since the 1960's, the continuous plankton recorder of the North Atlantic has shown an order of magnitude increase in coccolithophore abundance (from $\sim 2$ to $20 \%$ ), with increases in $\mathrm{CO}_{2}$ and temperature anomalies tracked through the Atlantic Multidecadal Oscillation identified as the highest probable environmental drivers of the change (Rivero-Calle et al., 2015). Thus OA, when combined with increasing temperatures, may not be as detrimental to this group of microbes as previously thought. Furthermore, coccolithophores hold a rapid adaptive potential to future ocean conditions. In a study of ecological relevance, Schlüter et al. (2014) showed that E. huxleyi underwent evolutionary adaptation after one year of being exposed to high temperatures and $\mathrm{CO}_{2}$. While cells had evolved to become smaller in size and contained less carbon, organic carbon cell 
quotas (PIC:POC) had been restored to initial levels owing to faster growth and increased production, with calcification rates also being partially restored.

The combined effects of increased $\mathrm{CO}_{2}$ and temperature on host-associated bacteria are also poorly understood. An increase in ocean temperature has been shown to cause a shift in the microbial community associated with corals and sponges (Bourne et al., 2008; Webster et al., 2008; Littman et al., 2010; Lee et al., 2015; Tracy et al., 2015), and new evidence suggests the effects of ocean $\mathrm{pH}$ and temperature are interactive. A recent laboratory study that incorporated variable $\mathrm{pH}$ and temperature conditions, demonstrated that the microbiomes of two Pacific corals species were fairly tolerant of elevated $\mathrm{pCO}_{2}$ (738$835 \mu \mathrm{atm}) /$ reduced $\mathrm{pH}(7.9)$ and elevated temperature $\left(31^{\circ} \mathrm{C}\right)$ (Webster et al., 2016). However, they detected an interactive effect between stressors ( $\mathrm{pH}$ and temperature), with $\mathrm{pCO}_{2}$ causing more divergent community compositions at higher temperatures, although this was not significant. Additionally, it is noteworthy that they found that sequences related to the putative coral symbiont, Endozoicomonas sp., were significantly reduced in A. millepora corals exposed to experimental OA conditions. In the case of reef corals, future studies may benefit from studying how the microbiome will respond to low $\mathrm{pH}$ and elevated temperature when hosting particular strains of Symbiodinium. For example, juvenile colonies of Acropora tenuis hosting Symbiodinium clade C1 maintained a stable bacterial community through a thermal stress event, while those who hosted clade D underwent shifts in associated bacterial communities (Littman et al., 2010). Since different phylotypes of Symbiodinium also show differential responses to increased $p \mathrm{CO}_{2}$ (Brading et al., 2011), it is possible that phylotypes that are more resistant to increases in $p \mathrm{CO}_{2}$ may also provide some stability for the associated microbial community.

The combined effects of $\mathrm{OA}$ and warming on marine diseases are complex, and early evidence suggests that the effect of one stressor on disease susceptibility may counteract the effect of the other. For example, antibacterial activity in the blue mussel was reduced by around $40 \%$ at low $\mathrm{pH}$ (6.5), but when the temperature was increased from 12.5 to $17^{\circ} \mathrm{C}$, antibacterial activity was restored to initial levels (Ellis et al., 2015). Conversely, the progression rate of coralline fungal disease (CFD) increased in crustose coralline algae (CCA) under elevated temperatures, however this rate increase was ameliorated under low pH (Williams et al., 2014). Reduced calcification of CCA was observed under low $\mathrm{pH}$ conditions, and it is possible this contributed to reduced disease progression. Many coral diseases are also known to display increased virulence under warmer ocean temperatures (Jones R. J. et al., 2004; Sato et al., 2009), and future research would benefit from studying pathogenesis under the combined effects of low $\mathrm{pH}$ and elevated temperature stress.

The interactive effects of $\mathrm{OA}$ and pollution on marine microbes are also complex and poorly understood, but are of high importance. Microbes are fundamental to environmental detoxification of pollutants and under low $\mathrm{pH}$ conditions the chemistry of environmental pollutants will change with implications for the way they interact with marine organisms (Coelho et al., 2013). Toxicity of pollutants may also be indirectly affected through $\mathrm{OA}$, given that as the composition of microbial communities change (Krause et al., 2012), so too may the detoxification processes provided by microbes. Metals that are involved in microbial growth and metabolism (e.g., iron) for example, may change in bioavailability with potentially harmful effects (Coelho et al., 2013). Coralassociated bacterial communities are sensitive to poor water quality (Bourne and Webster, 2013), sedimentation (Pollock et al., 2014), and elevated dissolved organic carbon (DOC). Higher DOC levels, correlated with human population growth and macroalgal overgrowth, are particularly detrimental and can cause microbial proliferation, oxygen depletion, and can disturb the holobiont equilibrium (Kline et al., 2006; Smith et al., 2006; Barott et al., 2011). However, the impact of these interactions under low $\mathrm{pH}$ conditions is still unknown.

\section{CONCLUSIONS AND FUTURE DIRECTIONS}

Anthropogenic $\mathrm{CO}_{2}$ emissions have unequivocally led to decreasing $\mathrm{pH}$ in our oceans, and the resulting consequences for marine microorganisms and their hosts are only just beginning to emerge. Both the carbon and nitrogen cycles are likely to be fundamentally altered through increased primary production, changes to calcification, increased nitrogen fixation, and reduced nitrification. However, microbial responses to $\mathrm{pH}$ vary among species, and natural $\mathrm{pH}$ fluctuations may provide some resilience to physiological changes. Additional long-term studies or mathematical models that replicate longterm scenarios are clearly required to further understand whether keystone microorganisms or microbial communities can and will adapt to OA. The majority of studies suggest that reduced $\mathrm{pH}$ will result in a shift in the microbial communities associated with invertebrate hosts, with direct impacts on host health and disease susceptibility, although the magnitude of effects will vary among species. Comparisons between microbial communities associated with invertebrate "winners" and "losers" at $\mathrm{CO}_{2}$ vent sites will provide important insights into future changes in acidifying oceans (Fabricius et al., 2011). Future studies should also focus on how the functional roles of host-associated microbes might be altered by OA, i.e., changes to photosynthetic capacity or nitrogen fixation. Finally, a better understanding of the synergistic effects of $\mathrm{OA}$ and other stressors is foremost. Microcosm and mesocosm experiments enable manipulative studies of the effects of multiple stressors on physiological processes in pelagic microbes (Coelho et al., 2013). For hostassociated microbes, taking advantage of thermal anomalies at $\mathrm{CO}_{2}$ vents may reveal insights into the combined effects of elevated temperature and OA in situ (Noonan and Fabricius, 2016). The potential for invertebrates to acquire new symbiotic microbes in an acidifying ocean, as well as adaptation of existing 
ones must also be explored, as it is this relationship that will define the existence of marine invertebrates in a future ocean.

\section{AUTHOR CONTRIBUTIONS}

PO: Substantial contributions to the conception or design of the work; Drafting the manuscript; KM, DB, and BW: Substantial contributions to the conception or design of the work. Revising the manuscript critically for important intellectual content.

\section{REFERENCES}

Asplund, M. E., Baden, S. P., Russ, S., Ellis, R. P., Gong, N., and Hernroth, B. E. (2014). Ocean acidification and host-pathogen interactions: blue mussels, Mytilus edulis, encountering Vibrio tubiashii. Environ. Microbiol. 16, 1029-1039. doi: 10.1111/1462-2920.12307

Azam, F., Fenchel, T., Field, J. G., Gray, J. S., Meyer-Reil, L. A., and Thingstad, F. (1983). The ecological role of water-column microbes in the sea. Mar. Ecol. Prog. Ser. 10, 257-263. doi: 10.3354/meps010257

Barneah, O., Ben-Dov, E., Kramarsky-Winter, E., and Kushmaro, A. (2007). Characterization of black band disease in Red Sea stony corals. Environ. Microbiol. 9, 1995-2006. doi: 10.1111/j.1462-2920.2007.01315.x

Barott, K. L., Rodriguez-Mueller, B., Youle, M., Marhaver, K. L., Vermeij, M. J., Smith, J. E., et al. (2011). Microbial to reef scale interactions between the reefbuilding coral Montastraea annularis and benthic algae. Proc. Biol. Sci. 279, 1655-1664. doi: 10.1098/rspb.2011.2155

Bayer, T., Arif, C., Ferrier-Pagès, C., Zoccola, D., Aranda, M., and Voolstra, C. R. (2013). Bacteria of the genus Endozoicomonas dominate the microbiome of the Mediterranean gorgonian coral Eunicella cavolini. Mar. Ecol. Prog. Ser. 479, 75-84. doi: 10.3354/meps10197

Beardall, J., and Raven, J. A. (2004). The potential effects of global climate change on microalgal photosynthesis, growth and ecology. Phycologica 43, 26-40. doi: 10.2216/i0031-8884-43-1-26.1

Beaufort, L., Probert, I., de Garidel-Thoron, T., Bendif, E. M., Ruiz-Pino, D., Metzl, N., et al. (2011). Sensitivity of coccolithophores to carbonate chemistry and ocean acidification. Nature 476, 80-83. doi: 10.1038/nature 10295

Bell, J. J., Davy, S. K., Jones, T., Taylor, M. W., and Webster, N. S. (2013). Could some coral reefs become sponge reefs as our climate changes? Glob. Chang. Biol. 19, 2613-2624. doi: 10.1111/gcb.12212

Bengen, D. G., Khoeri, M. M., Marhaeni, B., Radjasa, O. K., Sabdono, A., and Sudoyo, H. (2011). Antifouling activity of bacterial symbionts of seagrasses against marine biofilm-forming bacteria. J. Environ. Protect. 02, 1245-1249. doi: $10.4236 /$ jep.2011.29143

Ben-Haim, Y., Thompson, F. L., Thompson, C. C., Cnockaert, M. C., Hoste, B., Swings, J., et al. (2003). Vibrio coralliilyticus sp. nov., a temperature-dependent pathogen of the coral Pocillopora damicornis. Int. J. Syst. Evol. Microbiol. 53(Pt 1), 309-315. doi: 10.1099/ijs.0.02402-0

Bordenstein, S. R., and Theis, K. R. (2015). Host biology in light of the microbiome: ten principles of holobionts and hologenomes. PLoS Biol. 13:e1002226. doi: 10.1371/journal.pbio.1002226

Borell, E. M., Steinke, M., Horwitz, R., and Fine, M. (2014). Increasing $\mathrm{pCO}_{2}$ correlates with low concentrations of intracellular dimethylsulfoniopropionate in the sea anemone Anemonia viridis. Ecol. Evol. 4, 441-449. doi: $10.1002 /$ ece 3.946

Bourne, D., Iida, Y., Uthicke, S., and Smith-Keune, C. (2008). Changes in coralassociated microbial communities during a bleaching event. ISME J. 2, 350-363. doi: 10.1038/ismej.2007.112

Bourne, D. G., Muirhead, A., and Sato, Y. (2011). Changes in sulfate-reducing bacterial populations during the onset of black band disease. ISME J. 5, 559-564. doi: 10.1038/ismej.2010.143

Bourne, D. G., van der Zee, M. J., Botte, E. S., and Sato, Y. (2013). Sulfur-oxidizing bacterial populations within cyanobacterial dominated coral disease lesions. Environ. Microbiol. Rep. 5, 518-524. doi: 10.1111/1758-2229.12055

Bourne, D. G., and Webster, N. S. (2013). "Coral reef bacterial communities", in The Prokaryotes, eds E. Rosenberg, E. F. DeLong, S. Lory, E. Stackebrandt, and F. Thompson (Berlin; Heidelberg: Springer), 163-187.

\section{FUNDING}

AIMS@JCU Supporting PO; ARC Super Science Fellowships proposal FS110200034 supporting Kathy Morrow.

\section{ACKNOWLEDGMENTS}

The authors would like to thank Tim Simmonds (AIMS) for help with figure preparations.

Bowen, J. L., Kearns, P. J., Holcomb, M., and Ward, B. B. (2013). Acidification alters the composition of ammonia-oxidizing microbial assemblages in marine mesocosms. Mar. Ecol. Prog. Ser. 492, 1-8. doi: 10.3354/meps10526

Boyd, P. W. (2011). Beyond ocean acidification. Nat. Geosci. 4, 273-274. doi: $10.1038 /$ ngeo 1150

Brading, P., Warner, M. E., Davey, P., Smith, D. J., Achterberg, E. P., and Suggett, D. J. (2011). Differential effects of ocean acidification on growth and photosynthesis among phylotypes of Symbiodinium (Dinophyceae). Limnol. Oceanogr. 56, 927-938. doi: 10.4319/lo.2011.56.3.0927

Capone, D. G. (2000). “The marine microbial nitrogen cycle," in Microbial Ecology of the Oceans, ed D. L. Kirchman (New York, NY: Wiley-Liss), 455-493.

Capone, D. G., Burns, J. A., Montoya, J. P., Subramaniam, A., Mahaffey, C., Gunderson, T., et al. (2005). Nitrogen fixation by Trichodesmium spp.: an important source of new nitrogen to the tropical and subtropical North Atlantic Ocean. Glob. Biogeochem. Cycles 19:GB2024. doi: 10.1029/2004GB002331

Capone, D. G., Zehr, L. P., Paerl, H. W., Bergman, B., and Carpenter, E. J. (1997). Trichodesmium, a globally significant marine cyanobacterium. Science 276, 1221-1229. doi: 10.1126/science.276.5316.1221

Cardini, U., Bednarz, V. N., Foster, R. A., and Wild, C. (2014). Benthic $\mathrm{N}_{2}$ fixation in coral reefs and the potential effects of human-induced environmental change. Ecol. Evol. 4, 1706-1727. doi: 10.1002/ece3.1050

Cardini, U., Bednarz, V. N., Naumann, M. S., van Hoytema, N., Rix, L., Foster, R. A., et al. (2015). Functional significance of dinitrogen fixation in sustaining coral productivity under oligotrophic conditions. Proc. Biol. Sci. 282:20152257. doi: $10.1098 / \mathrm{rspb} .2015 .2257$

Cervino, J. M., Thompson, F. L., Gomez-Gil, B., Lorence, E. A., Goreau, T. J., Hayes, R. L., et al. (2008). The Vibrio core group induces yellow band disease in Caribbean and Indo-Pacific reef-building corals. J. Appl. Microbiol. 105, 1658-1671. doi: 10.1111/j.1365-2672.2008.03871.x

Coelho, F. J., Santos, A. L., Coimbra, J., Almeida, A., Cunha, A., Cleary, D. F., et al. (2013). Interactive effects of global climate change and pollution on marine microbes: the way ahead. Ecol. Evol. 3, 1808-1818. doi: 10.1002/ece3.565

Cornwall, C. E., and Hurd, C. L. (2016). Experimental design in ocean acidification research: problems and solutions. ICES J. Mar. Sci. 73, 572-581. doi: 10.1093/icesjms/fsv118

Dang, H., and Lovell, C. R. (2016). Microbial surface colonization and biofilm development in marine environments. Microbiol. Mol. Biol. Rev. 80, 91-138. doi: 10.1128/MMBR.00037-15

De Beer, D., and Larkum, A. W. D. (2001). Photosynthesis and calcification in the calcifying algae Halimeda discoidea studied with microsensors. Plant Cell Environ. 24, 1209-1217. doi: 10.1046/j.1365-3040.2001.00772.x

D’Elia, C. F., and Wiebe, W. J. (1990). "Biogeochemical nutrient cycles in coral-reef ecosystems," in Coral Reefs, ed Z. Dubinsky (Amsterdam: Elsevier), 49-74.

Denner, E. B., Smith, G. W., Busse, H. J., Schumann, P., Narzt, T., Polson, S. W., et al. (2003). Aurantimonas coralicida gen. nov., sp. nov., the causative agent of white plague type II on Caribbean scleractinian corals. Int. J. Syst. Evol. Microbiol. 53(Pt 4), 1115-1122. doi: 10.1099/ijs.0.02359-0

Domingues, A. M., Church, J. A., White, N. J., Gleckler, P. J., Wijffels, S. E., Barker, P. M., et al. (2008). Improved estimates of upper-ocean warming and multidecadal sea level rise. Nature 453, 1090-1094. doi: 10.1038/nature07080

Doney, S. C. (2010). The growing human footprint on coastal and openocean biogeochemistry. Science 328, 1512-1516. doi: 10.1126/science. 1185198

Doney, S. C., Fabry, V. J., Feely, R. A., and Kleypas, J. A. (2009). Ocean acidification: the other CO2 problem. Ann. Rev. Mar. Sci. 1, 169-192. doi: 10.1146/annurev.marine.010908.163834 
Duperron, S., Lorion, J., Samadi, S., Gros, O., and Gaill, F. (2009). Symbioses between deep-sea mussels (Mytilidae: Bathymodiolinae) and chemosynthetic bacteria: diversity, function and evolution. C. R. Biol. 332, 298-310. doi: 10.1016/j.crvi.2008.08.003

Ellis, R. P., Widdicombe, S., Parry, H., Hutchinson, T. H., and Spicer, J. I. (2015). Pathogenic challenge reveals immune trade-off in mussels exposed to reduced seawater $\mathrm{pH}$ and increased temperature. J. Exp. Mar. Biol. Ecol. 462, 83-89. doi: 10.1016/j.jembe.2014.10.015

Erez, J., Reynaud, S., Silverman, J., Schneider, K., and Allemand, D. (2011). “Coral calcification under ocean acidification and global change," in Coral Reefs: An Ecosystem in Transition, eds Z. Dubinsky, and N. Stambler (Springer), 151-176.

Erwin, P. M., and Thacker, R. W. (2008). Cryptic diversity of the symbiotic cyanobacterium Synechococcus spongiarum among sponge hosts. Mol. Ecol. 17, 2937-2947. doi: 10.1111/j.1365-294X.2008.03808.x

Fabricius, K. E., De'ath, G., Noonan, S., and Uthicke, S. (2014). Ecological effects of ocean acidification and habitat complexity on reef-associated macroinvertebrate communities. Proc. Biol. Sci. 281:20132479. doi: 10.1098/rspb.2013.2479

Fabricius, K. E., Langdon, C., Uthicke, S., Humphrey, C., Noonan, S., De'ath, G., et al. (2011). Losers and winners in coral reefs acclimatized to elevated carbon dioxide concentrations. Nat. Clim. Chang. 1, 165-169. doi: 10.1038/nclimate1122

Fan, L., Liu, M., Simister, R., Webster, N. S., and Thomas, T. (2013). Marine microbial symbiosis heats up: the phylogenetic and functional response of a sponge holobiont to thermal stress. ISME J. 7, 991-1002. doi: 10.1038/ismej.2012.165

Field, C. B., Behrenfeld, M. J., Randerson, J. T., and Falkowski, P. (1998). Primary production of the biosphere: integrating terrestrial and oceanic components. Science 281, 237-240. doi: 10.1126/science.281.5374.237

Fine, M., and Loya, Y. (2002). Endolithic algae: an alternative source of photoassimilates during coral bleaching. Proc. Biol. Sci. 269, 1205-1210. doi: 10.1098/rspb.2002.1983

Fu, F.-X., Warner, M. E., Zhang, Y., Feng, Y., and Hutchins, D. A. (2007). Effects of increased temperature and $\mathrm{CO} 2$ on photosynthesis, growth, and elemental ratios in marine Synechococcus and Prochlorococcus (Cyanobacteria). J. Phycol. 43, 485-496. doi: 10.1111/j.1529-8817.2007.00355.x

Gilbert, J. A., Field, D., Swift, P., Newbold, L., Oliver, A., Smyth, T., et al. (2009). The seasonal structure of microbial communities in the Western English Channel. Environ. Microbiol. 11, 3132-3139. doi: 10.1111/j.14622920.2009.02017.x

Gilbert, J. A., Meyer, F., Jansson, J., Gordon, J., Pace, N., Tiedje, J., et al. (2010). The earth microbiome project: meeting report of the "1st EMP meeting on sample selection and acquisition" at Argonne National Laboratory October 6th 2010. Stand. Genomic Sci. 3, 249-253. doi: 10.4056/aigs.1443528

Gilbert, J. A., Steele, J. A., Caporaso, J. G., Steinbruck, L., Reeder, J., Temperton, B., et al. (2012). Defining seasonal marine microbial community dynamics. ISME J. 6, 298-308. doi: 10.1038/ismej.2011.107

Giovannoni, S. J., and Stingl, U. (2005). Molecular diversity and ecology of microbial plankton. Nature 437, 343-348. doi: 10.1038/nature04158

Godbold, J. A., and Calosi, P. (2013). Ocean acidification and climate change: advances in ecology and evolution. Philos. Trans. R. Soc. Lond. B Biol. Sci. 368:20120448. doi: 10.1098/rstb.2012.0448

Goodwin, C., Rodolfo-Metalpa, R., Picton, B., and Hall-Spencer, J. M. (2014). Effects of ocean acidification on sponge communities. Mar. Ecol. 35, 41-49. doi: $10.1111 /$ maec. 12093

Guinotte, J. M., and Fabry, V. J. (2008). Ocean acidification and its potential effects on marine ecosystems. Ann. N.Y. Acad. Sci. 1134, 320-342. doi: 10.1196/annals. 1439.013

Hall-Spencer, J. M., Rodolfo-Metalpa, R., Martin, S., Ransome, E., Fine, M., Turner, S. M., et al. (2008). Volcanic carbon dioxide vents show ecosystem effects of ocean acidification. Nature 454, 96-99. doi: 10.1038/nature07051

Hassenruck, C., Hofmann, L. C., Bischof, K., and Ramette, A. (2015). Seagrass biofilm communities at a naturally $\mathrm{CO} 2$-rich vent. Environ. Microbiol. Rep. 7, 516-525. doi: 10.1111/1758-2229.12282

Hoegh-Guldberg, O., Mumby, P. J., Hooten, A. J., Steneck, R. S., Greenfield, P., Gomez, E., et al. (2007). Coral reefs under rapid climate change and ocean acidification. Science 318, 1737-1742. doi: 10.1126/science. 1152509
Hutchins, D. A. (2011). Forecasting the rain ratio. Nature 476, 41-42. doi: $10.1038 / 476041 \mathrm{a}$

Hutchins, D. A., Fu, F.-X., Zhang, Y., Warner, M. E., Feng, Y., Portune, K., et al. (2007). $\mathrm{CO}_{2}$ control of Trichodesmium $\mathrm{N}_{2}$ fixation, photosynthesis, growth rates, and elemental ratios: implications for past, present, and future ocean biogeochemistry. Limnol. Oceanogr. 52, 1293-1304. doi: 10.4319/lo.2007.52.4.1293

Iglesias-Rodriguez, M. D., Halloran, P. R., Rickaby, R. E., Hall, I. R., ColmeneroHidalgo, E., Gittins, J. R., et al. (2008). Phytoplankton calcification in a highCO2 world. Science 320, 336-340. doi: 10.1126/science.1154122

Jin, P., Gao, K., and Beardall, J. (2013). Evolutionary responses of a coccolithophorid Gephyrocapsa oceanica to ocean acidification. Evolution 67, 1869-1878. doi: 10.1111/evo.12112

Joint, I., Doney, S. C., and Karl, D. M. (2011). Will ocean acidification affect marine microbes? ISME J. 5, 1-7. doi: 10.1038/ismej.2010.79

Jones, G. P., McCormick, M. I., Srinivasan, M., and Eagle, J. V. (2004). Coral decline threatens fish biodiversity in marine reserves. Proc. Natl. Acad. Sci. U.S.A. 101, 8251-8253. doi: 10.1073/pnas.0401277101

Jones, R. J., Bowyer, J., Hoegh-Guldberg, O., and Blackall, L. L. (2004). Dynamics of a temperature-related coral disease outbreak. Mar. Ecol. Prog. Ser. 281, 63-77. doi: $10.3354 /$ meps 281063

Karl, D. M., and Church, M. J. (2014). Microbial oceanography and the Hawaii Ocean Time-series programme. Nat. Rev. Microbiol. 12, 699-713. doi: 10.1038/nrmicro3333

Kimura, M. (1980). A simple method for estimating evolutionary rate of base substitutions through comparative studies of nucleotide sequences. J. Mol. Evol. 16, 111-120. doi: 10.1007/BF01731581

Kline, D. I., Kuntz, N. M., Breitbart, M., Knowlton, N., and Rohwer, F. (2006). Role of elevated organic carbon levels and microbial activity in coral mortality. Mar. Ecol. Prog. Ser. 314, 119-125. doi: 10.3354/meps314119

Kranz, S. A., Sültemeyer, D., Richter, K., and Rost, B. (2009). Carbon acquisition by Trichodesmium: the effect of pCO2 and diurnal changes. Limnol. Oceanogr. 54, 548-559. doi: 10.4319/lo.2009.54.2.0548

Krause, E., Wichels, A., Giménez, L., and Gerdts, G. (2013). Marine fungi may benefit from ocean acidification. Aquat. Microbial. Ecol. 69, 59-67. doi: 10.3354/ame01622

Krause, E., Wichels, A., Gimenez, L., Lunau, M., Schilhabel, M. B., and Gerdts, G. (2012). Small changes in $\mathrm{pH}$ have direct effects on marine bacterial community composition: a microcosm approach. PLoS ONE 7:e47035. doi: 10.1371/journal.pone.0047035

Kühl, M., Cohen, Y., Dalsgaard, T., Jørgensen, B. B., and Revsbech, N. P. (1995). Microenvironment and photosynthesis of zooxanthellae in scleractinian corals studied with microsensors for O2, pH and light. Mar. Ecol. Prog. Ser. 117, 159-172. doi: 10.3354/meps117159

Kushmaro, A., Banin, E., Loya, Y., Stackebrandt, E., and Rosenberg, E. (2001). Vibrio shiloi sp. nov., the causative agent of bleaching of the coral Oculina patagonica. Int. J. Syst. Evol. Microbiol. 51, 1383-1388. doi: 10.1099/0020771351-4-1383

Langer, G., Nehrke, G., Probert, I., Ly, J., and Ziveri, P. (2009). Strain-specific responses of Emiliania huxleyi to changing seawater carbonate chemistry. Biogeosci. Discuss. 6, 4361-4383. doi: 10.5194/bgd-6-4361-2009

Larkum, A. W. D., Kennedy, I. R., and Muller, W. J. (1988). Nitrogen fixation on a coral reef. Mar. Biol. 98, 143-155. doi: 10.1007/BF00392669

Leblud, J., Moulin, L., Batigny, A., Dubois, P., and Grosjean, P. (2014). Technical note: artificial coral reef mesocosms for ocean acidification investigations. Biogeosci. Discuss. 11, 15463-15505. doi: 10.5194/bgd-11-15463-2014

Lee, S. T., Davy, S. K., Tang, S. L., Fan, T. Y., and Kench, P. S. (2015). Successive shifts in the microbial community of the surface mucus layer and tissues of the coral Acropora muricata under thermal stress. FEMS Microbiol. Ecol. 91:fiv142. doi: $10.1093 / \mathrm{femsec} /$ fiv142

Lema, K. A., Bourne, D. G., and Willis, B. L. (2014b). Onset and establishment of diazotrophs and other bacterial associates in the early life history stages of the coral Acropora millepora. Mol. Ecol. 23, 4682-4695. doi: 10.1111/mec.12899

Lema, K. A., Willis, B. L., and Bourne, D. G. (2012). Corals form characteristic associations with symbiotic nitrogen-fixing bacteria. Appl. Environ. Microbiol. 78, 3136-3144. doi: 10.1128/AEM.07800-11

Lema, K. A., Willis, B. L., and Bourne, D. G. (2014a). Amplicon pyrosequencing reveals spatial and temporal consistency in diazotroph assemblages of the 
Acropora millepora microbiome. Environ. Microbiol. 16, 3345-3359. doi: 10.1111/1462-2920.12366

Lesser, M. P., and Blakemore, R. P. (1990). Description of a novel symbiotic bacterium from the brittle star, Amphipholis squamata. Appl. Environ. Microbiol. 56, 2436-2440.

Lesser, M. P., Mazel, C. H., Gorbunov, M. Y., and Falkowski, P. G. (2004). Discovery of symbiotic nitrogen-fixing cyanobacteria in corals. Science 305, 997-1000. doi: 10.1126/science.1099128

Levitan, O., Rosenberg, G., Setlik, I., Setlikova, E., Grigel, J., Klepetar, J., et al. (2007). Elevated $\mathrm{CO}_{2}$ enhances nitrogen fixation and growth in the marine cyanobacterium Trichodesmium. Glob. Chang. Biol. 13, 531-538. doi: 10.1111/j.1365-2486.2006.01314.x

Li, J., Chen, Q., Long, L. J., Dong, J., Yang, J., and Zhang, S. (2014). Bacterial dynamics within the mucus, tissue and skeleton of the coral Porites lutea during different seasons. Sci. Rep. 4:7320. doi: 10.1038/srep07320

Littman, R. A., Bourne, D. G., and Willis, B. L. (2010). Responses of coralassociated bacterial communities to heat stress differ with Symbiodinium type on the same coral host. Mol. Ecol. 19, 1978-1990. doi: 10.1111/j.1365294X.2010.04620.x

Liu, J., Weinbauer, M. G., Maier, C., Dai, M., and Gattuso, J. P. (2010). Effect of ocean acidification on microbial diversity and on microbe-driven biogeochemistry and ecosystem functioning. Aquat. Microbial. Ecol. 61, 291-305. doi: 10.3354/ame01446

Lohbeck, K. T., Riebesell, U., and Reusch, T. B. H. (2012). Adaptive evolution of a key phytoplankton species to ocean acidification. Nat. Geosci. 5, 346-351. doi: 10.1038/ngeo1441

Luna, G. M., Bongiorni, L., Gili, C., Biavasco, F., and Danovaro, R. (2010). Vibrio harveyi as a causative agent of the White Syndrome in tropical stony corals. Environ. Microbiol. Rep. 2, 120-127. doi: 10.1111/j.1758-2229.2009.00114.x

McFall-Ngai, M. J. (1999). Consequences of evolving with bacterial symbionts: insights from the Squid-Vibrio associations. Annu. Rev. Ecol. Syst. 30, 235-256. doi: 10.1146/annurev.ecolsys.30.1.235

Meron, D., Atias, E., Iasur Kruh, L., Elifantz, H., Minz, D., Fine, M., et al. (2011). The impact of reduced $\mathrm{pH}$ on the microbial community of the coral Acropora eurystoma. ISME J. 5, 51-60. doi: 10.1038/ismej.2010.102

Meron, D., Rodolfo-Metalpa, R., Cunning, R., Baker, A. C., Fine, M., and Banin, E. (2012). Changes in coral microbial communities in response to a natural $\mathrm{pH}$ gradient. ISME J. 6, 1775-1785. doi: 10.1038/ismej.2012.19

Moberg, F., and Folke, C. (1999). Ecological goods and services of coral reef ecosystems. Ecol. Econ. 29, 215-233. doi: 10.1016/S0921-8009(99)00009-9

Montoya, J. P., Holl, C. M., Zehr, J. P., Hansen, A., Villareal, T. A., and Capone, D. G. (2004). High rates of $\mathrm{N}_{2}$ fixation by unicellular diazotrophs in the oligotrophic Pacific Ocean. Nature 430, 1027-1031. doi: 10.1038/nature02824

Moran, M. A., González, J. M., and Kiene, R. P. (2003). Linking a bacterial taxon to sulfur cycling in the sea: studies of the marine Roseobacter group. Geomicrobiol. J. 20, 375-388. doi: 10.1080/01490450303901

Moran, N. A., and Sloan, D. B. (2015). The hologenome concept: helpful or hollow? PLoS Biol. 13:e1002311. doi: 10.1371/journal.pbio.1002311

Morrow, K. M., Bourne, D. G., Humphrey, C., Botte, E. S., Laffy, P., Zaneveld, J., et al. (2014). Natural volcanic CO seeps reveal future trajectories for host-microbial associations in corals and sponges. ISME J. 9, 894-908. doi: 10.1038 /ismej.2014.188

Morrow, K. M., Moss, A. G., Chadwick, N. E., and Liles, M. R. (2012). Bacterial associates of two Caribbean coral species reveal species-specific distribution and geographic variability. Appl. Environ. Microbiol. 78, 6438-6449. doi: 10.1128/AEM.01162-12

Neave, M. J., Michell, C. T., Apprill, A., and Voolstra, C. R. (2014). Whole-genome sequences of three symbiotic Endozoicomonas strains. Genome Announc. 2, e00802-e00814 . doi: 10.1128/genomeA.00802-14

Nelson, C. E., Goldberg, S. J., Wegley, L. K., Haas, A. F., Smith, J. E., Rohwer, F., et al. (2013). Coral and macroalgal exudates vary in neutral sugar composition and differentially enrich reef bacterioplankton lineages. ISME J. 7, 962-979. doi: 10.1038 /ismej.2012.161

Noonan, S. H., and Fabricius, K. E. (2016). Ocean acidification affects productivity but not the severity of thermal bleaching in some tropical corals. ICES J. Mar. Sci. 73, 715-726. doi: 10.1093/icesjms/fsv127

Orr, J. C., Fabry, V. J., Aumont, O., Bopp, L., Doney, S. C., Feely, R. A., et al. (2005). Anthropogenic ocean acidification over the twenty-first century and its impact on calcifying organisms. Nature 437, 681-686. doi: 10.1038/nature04095
Partensky, F., Blanchot, J., and Vaulot, D. (1999). Differential distribution and ecology of Prochlorococcus and Synechococcus in oceanic waters: a review. Bull. Inst. Oceanogr. Monaco 19, 457-476.

Patterson, K. L., Porter, J. W., Ritchie, K. B., Polson, S. W., Mueller, E., Peters, E. C., et al. (2002). The etiology of white pox, a lethal disease of the Caribbean elkhorn coral, Acropora palmata. Proc. Natl. Acad. Sci. U.S.A. 99, 8725-8730. doi: 10.1073/pnas.092260099

Pearson, P. N., and Palmer, M. R. (2000). Atmospheric carbon dioxide concentrations over the past 60 million years. Nature 406, 695-699 doi: $10.1038 / 35021000$

Pollock, F. J., Lamb, J. B., Field, S. N., Heron, S. F., Schaffelke, B., Shedrawi, G., et al. (2014). Sediment and turbidity associated with offshore dredging increase coral disease prevalence on nearby reefs. PLOS ONE 9:e102498. doi: 10.1371/journal.pone. 0102498

Pomeroy, L. R., Williams, P. J., Azam, F., and Hobbie, J. E. (2007). The microbial loop. Oceanography 20, 28-33. doi: 10.5670/oceanog.2007.45

Pommerening-Roser, A., and Koops, H. P. (2005). Environmental pH as an important factor for the distribution of urease positive ammonia-oxidizing bacteria. Microbiol. Res. 160, 27-35. doi: 10.1016/j.micres.2004.09.006

Rädecker, N., Meyer, F. W., Bednarz, V. N., Cardini, U., and Wild, C. (2014), Ocean acidification rapidly reduces dinitrogen fixation associated with the hermatypic coral Seriatopora hystrix. Mar. Ecol. Prog. Ser. 511, 297-302. doi: 10.3354/meps10912

Rädecker, N., Pogoreutz, C., Voolstra, C. R., Wiedenmann, J., and Wild, C. (2015). Nitrogen cycling in corals: the key to understanding holobiont functioning? Trends Microbiol. 23, 490-497. doi: 10.1016/j.tim.2015.03.008

Raina, J. B., Dinsdale, E. A., Willis, B. L., and Bourne, D. G. (2010). Do the organic sulfur compounds DMSP and DMS drive coral microbial associations? Trends Microbiol. 18, 101-108. doi: 10.1016/j.tim.2009.12.002

Raina, J. B., Tapiolas, D. M., Foret, S., Lutz, A., Abrego, D., Ceh, J., et al. (2013). DMSP biosynthesis by an animal and its role in coral thermal stress response. Nature 502, 677-680. doi: 10.1038/nature12677

Raina, J. B., Tapiolas, D., Willis, B. L., and Bourne, D. G. (2009). Coral-associated bacteria and their role in the biogeochemical cycling of sulfur. Appl. Environ. Microbiol. 75, 3492-3501. doi: 10.1128/AEM.02567-08

Rasoulouniriana, D., Siboni, N., Ben-Dov, E., Kramarsky-Winter, E., Loya, Y., and Kushmaro, A. (2009). Pseudoscillatoria coralii gen. nov., sp. nov., a cyanobacterium associated with coral black band disease (BBD). Dis. Aquat. Organ 87, 91-96. doi: 10.3354/dao02089

Reshef, L., Koren, O., Loya, Y., Zilber-Rosenberg, I., and Rosenberg, E. (2006). The coral probiotic hypothesis. Environ. Microbiol. 8, 2068-2073. doi: 10.1111/j.1462-2920.2006.01148.x

Rhein, M., Rintoul, S. R., Aoki, S., Campos, E., Chambers, D., Feely, R. A., et al. (2013). "Observations: ocean," in Climate Change 2013: The Physical Science Basis. Intergovernmental Panel on Climate Change, Working Group I Contribution to the IPCC Fifth Assessment Report (AR5) (New York, NY: Cambridge Univ Press).

Riebesell, U., Schulz, K. G., Bellerby, R. G., Botros, M., Fritsche, P., Meyerhofer, M., et al. (2007). Enhanced biological carbon consumption in a high CO2 ocean. Nature 450, 545-548. doi: 10.1038/nature06267

Riebesell, U., Zondervan, I., Rost, B., Tortell, P. D., Zeebe, R. E., and Morel, F. M. M. (2000). Reduced calcifcation of marine plankton in response to increased atmospheric CO2. Nature 407, 364-367. doi: 10.1038/35030078

Ritchie, K. B. (2006). Regulation of microbial populations by coral surface mucus and mucus-associated bacteria. Mar. Ecol. Prog. Ser. 322, 1-14. doi: $10.3354 /$ meps 322001

Rivero-Calle, S., Gnanadesikan, A., Del Castillo, C. E., Balch, W., and Guikema, S. D. (2015). Multidecadal increase in North Atlantic coccolithophores and the potential role of rising CO2. Science 350, 1533-1537. doi: $10.1126 /$ science.aaa 8026

Roeselers, G., and Newton, I. L. (2012). On the evolutionary ecology of symbioses between chemosynthetic bacteria and bivalves. Appl. Microbiol. Biotechnol. 94, 1-10. doi: 10.1007/s00253-011-3819-9

Rohwer, F., Seguritan, V., Azam, F., and Knowlton, N. (2002). Diverstiy and distribution of coral-associated bacteria Mar. Ecol. Prog. Ser. 243, 1-10. doi: 10.3354/meps243001

Rosenberg, E., Koren, O., Reshef, L., Efrony, R., and Zilber-Rosenberg, I. (2007). The role of microorganisms in coral health, disease and evolution. Nat. Rev Microbiol. 5, 355-362. doi: 10.1038/nrmicro1635 
Royal Society (2005). Ocean Acidification due to Increasing Atmospheric Carbon Dioxide. Document 12/05, Royal Society (London).

Sand-Jensen, K. A. J. (1977). Effect of epiphytes on eelgrass photosynthesis. Aquat. Bot. 3, 55-63. doi: 10.1016/0304-3770(77)90004-3

Sato, Y., Bourne, D. G., and Willis, B. L. (2009). Dynamics of seasonal outbreaks of black band disease in an assemblage of Montipora species at Pelorus Island (Great Barrier Reef, Australia). Proc. Biol. Sci. 276, 2795-2803. doi: 10.1098/rspb.2009.0481

Sato, Y., Willis, B. L., and Bourne, D. G. (2010). Successional changes in bacterial communities during the development of black band disease on the reef coral, Montipora hispida. ISME J. 4, 203-214. doi: 10.1038/ismej.2009.103

Schlüter, L., Lohbeck, K. T., Gutowska, M. A., Gröger, J. P., Riebesell, U., and Reusch, T. B. H. (2014). Adaptation of a globally important coccolithophore to ocean warming and acidification. Nat. Clim. Change 4, 1024-1030. doi: 10.1038/nclimate2379

Schmitt, S., Tsai, P., Bell, J., Fromont, J., Ilan, M., Lindquist, N., et al. (2012). Assessing the complex sponge microbiota: core, variable and speciesspecific bacterial communities in marine sponges. ISME J. 6, 564-576. doi: 10.1038/ismej.2011.116

Sett, S., Bach, L. T., Schulz, K. G., Koch-Klavsen, S., Lebrato, M., and Riebesell, U. (2014). Temperature modulates coccolithophorid sensitivity of growth, photosynthesis and calcification to increasing seawater pCO(2). PLoS ONE 9:e88308. doi: 10.1371/journal.pone.0088308

Shashar, N., Feldstein, T., Cohen, Y., and Loya, Y. (1994). Nitrogen fixation (acetylene reduction) on a coral reef. Coral Reefs 13, 171-174. doi: 10.1007/BF00301195

Smith, J. E., Shaw, M., Edwards, R. A., Obura, D., Pantos, O., Sala, E., et al. (2006). Indirect effects of algae on coral: algae mediated, microbe induced coral mortality. Ecol. Lett. 9, 835-845. doi: 10.1111/j.1461-0248.2006.00937.x

Steinberg, D. K., Carlson, C. A., Bates, N. R., Johnson, R. J., Michaels, A. F., and Knap, A. H. (2001). Overview of the US JGOFS Bermuda Atlantic Time-series Study (BATS): a decade-scale look at ocean biology and biogeochemistry. Deep Sea Res. II 48, 1405-1447. doi: 10.1016/S0967-0645(00)00148-X

Strahl, J., Stolz, I., Uthicke, S., Vogel, N., Noonan, S. H., and Fabricius, K. E. (2015). Physiological and ecological performance differs in four coral taxa at a volcanic carbon dioxide seep. Comp. Biochem. Physiol. A Mol. Integr. Physiol. 184, 179-186. doi: 10.1016/j.cbpa.2015.02.018

Sunagawa, S., DeSantis, T. Z., Piceno, Y. M., Brodie, E. L., DeSalvo, M. K., Voolstra, C. R. et al. (2015). Structure and function of the global ocean microbiome. Science 348:1261359. doi: 10.1126/science. 1261359

Sunagawa, S., DeSantis, T. Z., Piceno, Y. M., Brodie, E. L., DeSalvo, M. K., Voolstra, C. R., et al. (2009). Bacterial diversity and White Plague Disease-associated community changes in the Caribbean coral Montastraea faveolata. ISME J. 3, 512-521. doi: 10.1038/ismej.2008.131

Sunagawa, S., Woodley, C. M., and Medina, M. (2010). Threatened corals provide underexplored microbial habitats. PLOS ONE 5:e9554. doi: 10.1371/journal.pone.0009554

Sunda, W., Kieber, D. J., Kiene, R. P., and Huntsman, S. (2002). An antioxidant function for DMSP and DMS in marine algae. Nature 418, 317-320. doi: 10.1038/nature00851

Sweet, M. J., Bythell, J. C., and Nugues, M. M. (2013). Algae as reservoirs for coral Pathogens. Plos One, 8:e69717. doi: 10.1371/journal.pone.0069717

Tamura, K., Stecher, G., Peterson, D., Filipski, A., and Kumar, S. (2013). MEGA6: molecular evolutionary genetics analysis version 6.0. Mol. Biol. Evol. 30, 2725-2729 doi: 10.1093/molbev/mst197

Thompson, F. L., Barash, Y., Sawabe, T., Sharon, G., Swings, J., and Rosenberg, E. (2006). Thalassomonas loyana sp. nov., a causative agent of the white plaguelike disease of corals on the Eilat coral reef. Int. J. Syst. Evol. Microbiol. 56(Pt 2), 365-368. doi: 10.1099/ijs.0.63800-0

Tracy, A., Koren, O., Douglas, N., Weil, E., and Harvell, D. (2015). Persistent shifts in caribbean coral microbiota are linked to the 2010 warm thermal anomaly. Environ. Microbiol. Rep. 7, 471-479. doi: 10.1111/1758-2229.12274

Vega Thurber, R., Willner-Hall, D., Rodriguez-Mueller, B., Desnues, C., Edwards, R. A., Angly, F., et al. (2009). Metagenomic analysis of stressed coral holobionts. Environ. Microbiol. 11, 2148-2163. doi: 10.1111/j.1462-2920.2009. 01935.x
Venn, A. A., Tambutte, E., Lotto, S., Zoccola, D., Allemand, D., and Tambutte, S. (2009). Imaging intracellular $\mathrm{pH}$ in a reef coral and symbiotic anemone. Proc. Natl. Acad. Sci. U.S.A. 106, 16574-16579. doi: 10.1073/pnas.0902894106

Ward, B. B. (2000). "Nitrification and the marine nitrogen cycle," in Microbial Ecology of the Ocean, ed D. L. Kirchman (New York, NY: Wiley-Liss), 427-454.

Webster, N., and Hill, R. (2007). "Chapter 5 Vulnerability of marine microbes on the Great Barrier Reef to climate change," in Climate Change and the Great Barrier Reef: A Vulnerability Assessment, eds J. E. Johnson and P. A. Marshall (Townsville: Great Barrier Reef Marine Park Authority and Australian Greenhouse Office), 97-120.

Webster, N. S., Cobb, R. E., and Negri, A. P. (2008). Temperature thresholds for bacterial symbiosis with a sponge. ISME J. 2, 830-842. doi: 10.1038/ismej.2008.42

Webster, N. S., Negri, A. P., Botté, E. S., Laffy, P. W., Flores, F., Noonan, S., et al. (2016). Host-associated coral reef microbes respond to the cumulative pressures of ocean warming and ocean acidification. Sci. Rep. 6:19324. doi: $10.1038 /$ srep 19324

Webster, N. S., Negri, A. P., Flores, F., Humphrey, C., Soo, R., Botte, E. S., et al. (2013a). Near-future ocean acidification causes differences in microbial associations within diverse coral reef taxa. Environ. Microbiol. Rep. 5, 243-251. doi: 10.1111/1758-2229.12006

Webster, N. S., and Taylor, M. W. (2012). Marine sponges and their microbial symbionts: love and other relationships. Environ. Microbiol. 14, 335-346. doi: 10.1111/j.1462-2920.2011.02460.x

Webster, N. S., Uthicke, S., Botté, E. S., Flores, F., and Negri, A. P. (2013b). Ocean acidification reduces induction of coral settlement by crustose coralline algae. Glob. Chang. Biol. 19, 303-315. doi: 10.1111/gcb.12008

Webster, N. S., Webb, R. I., Ridd, M. J., Hill, R. T., and Negri, A. P. (2001). The effects of copper on the microbial community of a coral reef sponge. Environ. Microbiol. 3, 19-31. doi: 10.1046/j.1462-2920.2001.00155.x

Welsh, E. A., Liberton, M., Stockel, J., Loh, T., Elvitigala, T., Wang, C., et al. (2008). The genome of Cyanothece 51142, a unicellular diazotrophic cyanobacterium important in the marine nitrogen cycle. Proc. Natl. Acad. Sci. U.S.A. 105, 15094-15099. doi: 10.1073/pnas.0805418105

White, A. T., Vogt, H. P., and Arin, T. (2000). Philippine coral reefs under threat: the economic losses caused by reef destruction. Mar. Pollut. Bull. 40, 598-605. doi: 10.1016/S0025-326X(00)00022-9

Williams, G. J., Price, N. N., Ushijima, B., Aeby, G. S., Callahan, S., Davy, S. K., et al. (2014). Ocean warming and acidification have complex interactive effects on the dynamics of a marine fungal disease. Proc. Biol. Sci. 281:20133069. doi: 10.1098/rspb.2013.3069

Yang, C. S., Chen, M. H., Arun, A. B., Chen, C. A., Wang, J. T., and Chen, W. M. (2010). Endozoicomonas montiporae sp. nov., isolated from the encrusting pore coral Montipora aequituberculata. Int. J. Syst. Evol. Microbiol. 60(Pt 5), 1158-1162. doi: 10.1099/ijs.0.014357-0

Yost, D. M., Jones, R. J., and Mitchelmore, C. L. (2010). Alterations in dimethylsulfoniopropionate (DMSP) levels in the coral Montastraea franksi in response to copper exposure. Aquat. Toxicol. 98, 367-373. doi: 10.1016/j.aquatox.2010.03.005

Zilber-Rosenberg, I., and Rosenberg, E. (2008). Role of microorganisms in the evolution of animals and plants: the hologenome theory of evolution. FEMS Microbiol. Rev. 32, 723-735. doi: 10.1111/j.1574-6976.2008.00123.x

Zondervan, I., Zeebe, R. E., Rost, B., and Riebesell, U. (2001). Decreasing marine biogenic calcification: a negative feedback on rising atmospheric pCO2. Glob. Biogeochem. Cycles 15, 507-516. doi: 10.1029/2000GB001321

Conflict of Interest Statement: The authors declare that the research was conducted in the absence of any commercial or financial relationships that could be construed as a potential conflict of interest.

Copyright $\odot 2016$ O'Brien, Morrow, Willis and Bourne. This is an open-access article distributed under the terms of the Creative Commons Attribution License (CC BY). The use, distribution or reproduction in other forums is permitted, provided the original author(s) or licensor are credited and that the original publication in this journal is cited, in accordance with accepted academic practice. No use, distribution or reproduction is permitted which does not comply with these terms. 